\title{
Soybean Rust Epidemics as Affected by Weather Conditions in Brazil
}

\author{
Gustavo C. Beruski ${ }^{1}$, Paulo C. Sentelhas ${ }^{1}$, André B. Pereira ${ }^{2}$, Gil M. S. Câmara ${ }^{1}$, Ivan P. A. Junior ${ }^{3}$ \\ \& Luis M. Schiebelbein ${ }^{2}$ \\ ${ }^{1}$ Agricultural College "Luiz de Queiroz", University of São Paulo, Piracicaba, SP, Brazil \\ ${ }^{2}$ State University of Ponta Grossa, Ponta Grossa, PR, Brazil \\ ${ }^{3}$ Mato Grosso Foundation, Rondonópolis, Brazil \\ Correspondence: Paulo C. Sentelhas, Department of Biosystems Engineering, Agricultural College "Luiz de \\ Queiroz", University of São Paulo, Av. Pádua Dias, 11, Zip code 13418-900 Piracicaba, SP, Brazil. Tel: \\ 55-19-3429-4283. E-mail: pcsentel.esalq@usp.br
}

Received: October 26, 2019

Accepted: November 26, 2019 Online Published: December 15, 2019

doi:10.5539/jas.v12n1p213

URL: https://doi.org/10.5539/jas.v12n1p213

\begin{abstract}
The soybean rust (SBR) epidemics are often triggered by weather conditions, which interfere actively on the disease progress. Therefore, weather variables can be used to estimate the risk of occurrence and severity of SBR outbreaks. This research aimed to determine the influence of weather variables on SBR progress in different field trials in Brazil. Field experiments were conducted during 2014-15 and 2015-16 soybean growing seasons in Piracicaba (SP), Ponta Grossa (PR), Campo Verde (MT) and Pedra Preta (MT). For all sites and seasons, a susceptible soybean cultivar was drilled with $0.45 \mathrm{~m}$ row spacing and 12 plants per linear meter. No fungicide sprays were applied to ensure natural disease occurrence. In order to create different environmental conditions, sequential sowing dates, of roughly 30-day intervals were carried out. In Piracicaba, Ponta Grossa, Campo Verde, and Pedra Preta the main weather variables influencing SBR were leaf wetness duration - LWD $(R=0.340)$, air temperature during $\operatorname{LWD}(\mathrm{R}=0.313)$, and cumulative rainfall $(\mathrm{R}=0.304)$. The final severity was assessed only at Piracicaba and Ponta Grossa, and it was mainly influenced by LWD $(R=0.643)$. It is possible to conclude that epidemics of SBR were mainly influenced by leaf wetness duration, accumulated rainfall and air temperature during the LWD. Therefore, future researches aiming to develop a disease warning system for SBR should include the cumulative rainfall, LWD and the air temperature during LWD, together or individually, as inputs.
\end{abstract}

Keywords: Glycine max, Phakopsora pachyrhizi, rainfall, leaf wetness duration

\section{Introduction}

Many factors contribute to reduce soybean production and among them, diseases are one of the most important (Strange \& Scott, 2005). However, for the establishment of disease, the existence of a susceptible host and favorable environmental conditions, which characterize the disease triangle, are necessary. Environmental conditions should be seen as the main triggering factor to promote disease occurrence in conjunction with the pathogen and host populations (Kranz \& Rotem, 2012).

Air temperature, relative humidity, rainfall, leaf wetness duration (LWD), solar radiation, and wind are the main weather variables that affect the infection process and disease spread in soybean fields (Cao et al., 2014). Weather regimes characterize the local climate, which can create favorable or unfavorable environmental conditions for disease occurrence. Furthermore, weather variables are directly linked with fungicide spray effectiveness, affording a better or lower level of disease control (Stefanello et al., 2016).

It is the fungal pathogen (Phakopsora pachyrhizi Syd. \& Syd.) that causes the disease soybean rust (SBR), which is affected by weather variables and controlled by fungicide spray. SBR is one of the most important diseases of soybean. This pathogen is an obligate parasitic fungus that infects all plant tissues, especially leaves, causing premature defoliation, early maturity, and yield reductions up to $90 \%$ under favorable conditions and with inefficient disease management (Yorinori et al., 2005; Hartman et al., 2016).

Air temperature can affect the whole SBR infection cycle by interfering and regulating the pathogen's metabolic reactions (Gillespie \& Sentelhas, 2008). At an optimum temperature range, metabolic reactions can be accelerated; as a consequence, a reduction in the infection cycle occurs, increasing the likelihood of disease 
occurrence (Bonde et al., 2013). Under Brazilian weather conditions Alves et al. (2007) evidenced a more intense SBR infection at an air temperature around $20^{\circ} \mathrm{C}$, culminating in a lower SBR infection when the air temperature remained below $15{ }^{\circ} \mathrm{C}$ or above $28{ }^{\circ} \mathrm{C}$. More recently, Danelli and Reis (2016) determined that air temperature conditioned SBR growth and development, with the largest number of spores, lesions, uredia, and uredias per lesion when temperatures were between $22{ }^{\circ} \mathrm{C}$ and $25^{\circ} \mathrm{C}$.

SBR occurrence in soybean crops is also influenced by local humidity conditions in light of rainfall, irrigation, dew and leaf wetness are to be the main source of moisture in soybean fields. Air humidity interferes with the initial development and establishment of SBR once it affects the pathogen germination and penetration processes (Alves et al., 2007; Sentelhas et al., 2008; Rowlandson et al., 2014). Moreover, high air humidity makes the host tissue thin, increasing the host susceptibility to pathogen infection (Gabriel et al., 2018). For fungal pathogens, such as $P$. pachyrhizi, the presence of free water on the host tissue is essential for spore longevity and viability, germination, infection and sporulation (Del Ponte \& Esker, 2008).

Leaf wetness duration (LWD) associated with air temperature during LWD events have a direct effect on SBR occurrence and dissemination, primarily by influencing the rate of infection (fungus germination and penetration) and sporulation (Igarashi et al., 2014). Hartman et al. (2016) found a positive interaction between LWD and SBR infection probability, with the highest disease severity occurring during days with 24 hours of LWD. While, Melching et al. (1989) observed that wet periods exceeding 10 hours for several consecutive days are optimal for SBR occurrence.

Besides air temperature and LWD, rainfall can also affect SBR occurrence. Rainfall regime is considered to be an epidemic triggering factor of SBR, by creating a favorable environment for the pathogen (Del Ponte et al., 2006; Megeto et al., 2014) and unfavorable for fungicide spray application in order to control the SBR (Stefanello et al., 2016). Influence of rainfall on SBR progress was observed in Brazil, where areas with rainfall between 250 and $450 \mathrm{~mm}$ showed final disease severity over $70 \%$; whereas areas with rainfall lower than 125 $\mathrm{mm}$ presented severity below $30 \%$ (Del Ponte et al., 2006).

Taking into account the interference of weather variables on SBR disease progress, the current study aimed to characterize the influence of weather variables (air temperature, relative humidity, rainfall and leaf wetness duration) on SBR disease progress at four different locations in Brazil: Piracicaba, state of São Paulo; Ponta Grossa, state of Paraná; Campo Verde and Pedra Preta, both in the state of Mato Grosso.

\section{Material and Methods}

Field experiments were conducted during both 2014-15 and 2015-16 growing seasons. For the first season, field trials were installed at Piracicaba, state of São Paulo (Lat. $22^{\circ} 42^{\prime} \mathrm{S}$, Long. $47^{\circ} 37^{\prime} \mathrm{W}$, Alt.: $567 \mathrm{~m}$, climate

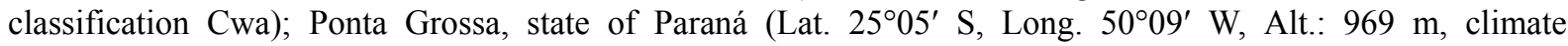

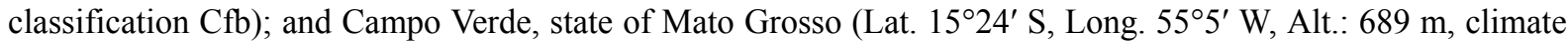
classification Aw). For the second season, in addition to the three field trials described above an additional experiment was also carried out in Pedra Preta, state of Mato Grosso (Lat. 16 $83^{\prime}$ S, Long. 54 $04^{\prime}$ W, Alt.: $744 \mathrm{~m}$, climate classification Aw)-Brazil. Köppen's climate classification was based on Alvares et al. (2013).

At Piracicaba and Ponta Grossa throughout the 2014-15 crop growing season, the field trial was conducted with Brasmax Potência RR ${ }^{\circledR}$ cultivar (indeterminate growth, and maturity group 6.7), during 2015-16 crop growing season the experiments were cultivated with Monsoy 6410 RR ${ }^{\circledR}$ IPRO ${ }^{\circledR}$ (indeterminate growth, and maturity group 6.4). At Campo Verde and Pedra Preta, a soybean cultivar TMG 132 RRß (determinate growth, and maturity group of 8.5) was sown for the two crop growing seasons. For all sites and seasons, the soybean crop was drilled with $0.45 \mathrm{~m}$ row spacing and 12 plants per linear meter, totaling 266,666 plants $^{-1} \mathrm{a}^{-1}$. In order to create different environmental conditions sequential sowing dates, of roughly 30 -day intervals, were used (Table $1)$. 
Table 1. Site locations and sowing dates to assess the effect of weather variables on soybean rust progress in Brazil

\begin{tabular}{|c|c|c|c|c|c|}
\hline Site & & & Sowing $\mathrm{d}$ & & \\
\hline Diropioh & $23 /$ Oct $/ 14$ & 18/Nov/14 & 12/Dec/14 & 20/Jan/15 & $19 / \mathrm{Feb} / 15$ \\
\hline Piracicaaa & $22 /$ Oct $/ 15$ & 19/Nov/15 & 18/Dec/15 & 20/Jan/16 & - \\
\hline Donta Grosco & $16 / \mathrm{Oct} / 14$ & $11 /$ Nov/14 & $18 / \mathrm{Dec} / 14$ & $01 / 15 / 15$ & - \\
\hline Ponta Grossa & $08 /$ Oct $/ 15$ & 21/Nov/15 & 11/Dec/15 & 23/Jan/16 & - \\
\hline$C_{-1}$ & $21 / \mathrm{Oct} / 14$ & $13 /$ Nov/14 & $12 / \mathrm{Dec} / 14$ & - & - \\
\hline Campo Verde & $23 /$ Oct $/ 15$ & 07/ Nov/15 & 09/Dec/15 & - & - \\
\hline Pedra Preta & $06 /$ Nov/15 & 03/Dec/15 & - & - & - \\
\hline
\end{tabular}

Note. In Piracicaba and Ponta Grossa throughout the 2014-15 season the cultivar sown was the Brasmax Potência RR® (indeterminate growth, and maturity group 6.7) while during 2015-16 the Monsoy $6410 \mathrm{RR} \circledast$ IPRO ${ }^{\circledR}$ (indeterminate growth, and maturity group 6.4) was sown. At Campo Verde and Pedra Preta, a soybean cultivar TMG $132 \mathrm{RR} \circledast$ (determinate growth, and maturity group of 8.5 ) was sown for the two growing seasons.

In all field trials, the experimental design adopted was randomized blocks, with four replications and treatments arranged in a factorial scheme. Treatments were the combination of sowing dates with soybean growing seasons. For Piracicaba and Ponta Grossa, plots were comprised of five sowing rows, each four meters long. At Campo Verde and Pedra Preta, plots presented five sowing rows with seven meters length.

Seed treatment was done with $200 \mathrm{~mL}$ of fungicide and pesticide (Pyraclostrobin, MetilTiofanato, and Fipronil) for each $100 \mathrm{~kg}$ of seeds. Soybean seeds were inoculated with Bradyrhizobia bacteria (Bradyrhizobium japonicum, strains SEMIA $5079 \& 5080$ ) with $5 \times 10^{9}$ colony forming unit (CFU) per mL. Inoculation was performed by mixing seeds with liquid inoculants prior to sowing the seeds. Mineral fertilization was done based on soil analysis and considering the expected yield. In Piracicaba and Ponta Grossa field trails, the soybean crop was fertilized with $100 \mathrm{~kg}$ of $\mathrm{P}_{2} \mathrm{O}_{5} \mathrm{ha}^{-1}$ and $100 \mathrm{~kg}$ of KCl ha- ${ }^{-1}$. In Campo Verde and Pedra Preta, the soybean fertilization was done with $152 \mathrm{~kg} \mathrm{ha}^{-1}$ of NPK (12-46-00), plus 7\% of sulfate and $150 \mathrm{~kg}$ of KCl ha- ${ }^{-1}$.

At each experimental site, an automatic weather station was installed close to the crop (from 5 to $15 \mathrm{~m}$ ) in order to monitor meteorological variables. Which was equipped with calibrated sensors to measure: air temperature (Air_T) and relative humidity (RH) (HMP35C probe, Vaisala); rainfall (TR-525M rain gauge, Texas Instruments) and leaf wetness duration (LWD) (Cylindrical Sensor, Weather Innovations). These sensors were connected to datalogger (Models CR10X and CR1000, Campbell Scientific, Logan UT), which were programmed to perform readings every minute and store averages (Air_T and RH) or totals (rainfall and LWD) every 15 minutes. All sensors were previously tested and calibrated under laboratory and field conditions.

To ensure SBR occurrence, susceptible cultivars were sown in all field trials. Furthermore, no fungicide sprays to control it were applied. As the pathogen is spread all over Brazilian agricultural lands and considering that weather conditions are constantly favorable, it was not necessary to perform inoculation so that the disease could naturally occur in the field.

Disease assessments were made in three central rows of each plot. At Piracicaba and Ponta Grossa shortly after SBR identification, assessments were made every 10 days throughout the entire soybean growing season till the beginning of maturation. In order to determine SBR severity, soybean plants were divided into three parts based on plant height: a) lower third, a region close to the soil surface; b) middle third, a central region of the soybean plant; c) upper third, in the higher part of the canopy. For each part four leaflets were randomly selected and severity assessments were ascribed based on a diagrammatic scale proposed by Godoy et al. (2006). For canopies with defoliation owing to SBR, the severity level was considered as $100 \%$.

At Campo Verde and Pedra Preta, disease assessments were performed at the R5.5 soybean phenological stage, which is characterized by pods between $75 \%$ and $100 \%$ of grain granulation. Moreover, at the end of the soybean growing season, canopy defoliation caused by SBR was determined. The defoliation assessments were realized when soybean plants reached the R7 phenological stage (beginning of maturation); therefore, visual evaluations were made following the defoliation severity scale proposed by Hirano et al. (2010). Based on SBR severity data collected in Piracicaba and Ponta Grossa, the area under the disease progress curve (AUDPC) was calculated.

To determine the weather influence on SBR epidemics a correlation analysis was performed to identify variables associated with final disease severity and AUDPC for Piracicaba and Ponta Grossa along with final defoliation 
for Campo Verde and Pedra Preta. Furthermore, the effects of weather conditions on SBR epidemics were performed comparing severity assessed in R5.5 stage and final severity with the mean air temperature during LWD (Air_LWD), LWD, cumulative Rainfall (C_Rainfall), mean air temperature (Air_T) and rainfall events (Rainfall_E). Correlation analyses were made using disease values with weather conditions measured 30 days before the severity assessment in soybean fields.

\section{Results and Discussion}

\subsection{Weather Characterization}

In Piracicaba, the mean air temperature for each sowing date remained between 22.9 and $24.7{ }^{\circ} \mathrm{C}$, which are within the optimum range for SBR development, which is considered to be in the range between 20 and $25{ }^{\circ} \mathrm{C}$ (Melching et al., 1989; Alves et al., 2007; Del Ponte \& Esker, 2008). However, air temperature above $25{ }^{\circ} \mathrm{C}$ during the two growing seasons was observed (Figure 1). Despite the air temperature being above the upper favorable threshold for disease occurrence, such condition was not able to reduce SBR final severity, which reached $94.1 \%$ in the first and $89.5 \%$ in the second growing season (Table 2). For the fifth sowing date in 2015-16, SBR was not observed, probably due to the occurrence of low temperatures combined with the absence of moisture, which was caused by the intense drought that occurred in this year.

Del Ponte et al. (2006) also reported evidence that air temperature is not a limiting factor for SBR occurrence in Brazil. In contrast, a downside in SBR epidemics due to high air temperature might be related in several studies. Alves et al. (2007) noted under tropical field conditions that urediniospores from different isolates did not germinate and appressoria did not grow in environments with air temperatures above $30^{\circ} \mathrm{C}$. In addition, Danelli and Reis (2016) verified no infection process whenever air temperature reached values higher than $30^{\circ} \mathrm{C}$.
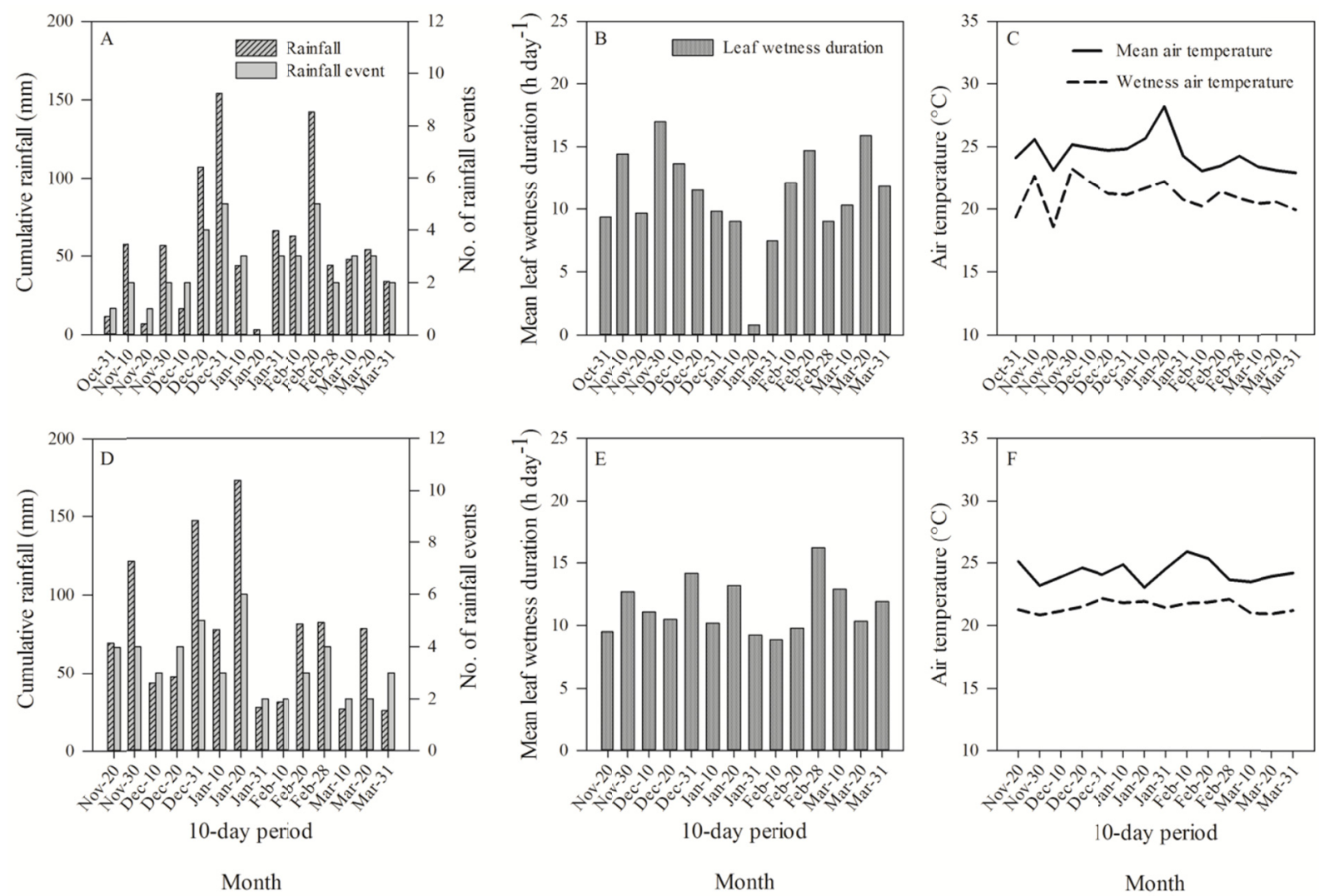

Figure 1. Weather conditions in Piracicaba, SP, during 2014-15 (A, B and C) and 2015-16 (D, E and F) soybean crop growing seasons 
Table 2. Final severity and area under the disease progress curve (AUDPC) caused by soybean rust in Piracicaba and Ponta Grossa throughout the 2014-15 and 2015-16 soybean growing seasons at different sowing dates

\begin{tabular}{|c|c|c|c|c|c|}
\hline \multicolumn{3}{|c|}{ Piracicaba-2014-15 } & \multicolumn{3}{|c|}{ Ponta Grossa-2014-15 } \\
\hline Sowing date & Final Severity (\%) & AUDPC & Sowing date & Final Severity (\%) & AUDPC \\
\hline $23 /$ Oct $/ 2014$ & $92.2 \mathrm{a}$ & $2287.5 \mathrm{a}$ & $16 / \mathrm{Oct} / 2014$ & $66.8 \mathrm{a}$ & $1676.8 \mathrm{a}$ \\
\hline 18/Nov/2014 & $100.0 \mathrm{a}$ & $1926.9 \mathrm{ab}$ & 11/Nov/2014 & $18.6 \mathrm{~b}$ & $555.5 \mathrm{c}$ \\
\hline 12/Dec/2014 & $100.0 \mathrm{a}$ & $1655.7 \mathrm{~b}$ & 18/Dec/2014 & $71.3 \mathrm{a}$ & $1073.7 \mathrm{~b}$ \\
\hline $20 / \mathrm{Jan} / 2015$ & $84.4 \mathrm{a}$ & $837.1 \mathrm{c}$ & $15 / \mathrm{Jan} / 2015$ & $81.0 \mathrm{a}$ & $1946.8 \mathrm{a}$ \\
\hline 19/Feb/2015 & $94.1 \mathrm{a}$ & $1726.2 \mathrm{~b}$ & - & - & - \\
\hline $\mathrm{CV}$ & $8.1 \%$ & $11.4 \%$ & $\mathrm{CV}$ & $14.5 \%$ & $14.2 \%$ \\
\hline \multicolumn{3}{|c|}{ Piracicaba-2015-16 } & \multicolumn{3}{|c|}{ Ponta Grossa-2015-16 } \\
\hline Sowing date & Final Severity (\%) & AUDPC & Sowing date & Final Severity (\%) & AUDPC \\
\hline $22 /$ Oct $/ 2015$ & $65.9 \mathrm{~b}$ & $1969.3 \mathrm{a}$ & 08/Oct/2015 & $73.7 \mathrm{a}$ & $577.2 \mathrm{a}$ \\
\hline 19/Nov/2015 & $97.2 \mathrm{a}$ & $1827.2 \mathrm{a}$ & $21 /$ Nov/2015 & $16.4 \mathrm{~b}$ & $243.9 \mathrm{bc}$ \\
\hline 18/Dec/2015 & $95.1 \mathrm{a}$ & $1144.9 \mathrm{~b}$ & 11/Dec/2015 & $12.1 \mathrm{~b}$ & $101.2 \mathrm{c}$ \\
\hline 20/Jan/2016 & $100.0 \mathrm{a}$ & $780.1 \mathrm{~b}$ & $23 / \mathrm{Jan} / 2016$ & $11.5 \mathrm{~b}$ & $277.3 \mathrm{~b}$ \\
\hline 19/Feb/2016 & $1.9 \mathrm{c}$ & $26.1 \mathrm{c}$ & - & - & - \\
\hline $\mathrm{CV}$ & $9.8 \%$ & $24.2 \%$ & $\mathrm{CV}$ & $8.1 \%$ & $22.7 \%$ \\
\hline
\end{tabular}

Note. The data followed by different letters are statistically different by the Tukey's test $(\alpha=0.05)$.

The high-temperature effects on SBR epidemics were also demonstrated in studies conducted in the Southeastern USA. Bonde et al. (2012) certified that air temperatures of 29,33 and $39{ }^{\circ} \mathrm{C}$ for one hour per day might reduce the urediniospore formation by 39,19 and $0 \%$, respectively, compared to temperatures within an optimum range of SBR development. Another factor that might interfere with SBR development is the frequency of high temperatures above $33{ }^{\circ} \mathrm{C}$. At different counties located in southern USA air temperatures above $33{ }^{\circ} \mathrm{C}$ decreased the SBR epidemics. Such effects were prominent whenever three consecutive days with air temperatures of $35^{\circ} \mathrm{C}$ were observed, and in this case 50\% fewer urediniospore were produced (Bonde et al., 2013).

The favorability to SBR occurrence at Piracicaba can be corroborated by analyses of the air temperature during LWD (Figure 1). Considering all sowing dates for the 2014-15 growing season, air temperature during LWD ranged from $18.2{ }^{\circ} \mathrm{C}$ to $23.2{ }^{\circ} \mathrm{C}$. Throughout the $2015-16$ growing season, air temperature varied from $14.4{ }^{\circ} \mathrm{C}$ to $22.2{ }^{\circ} \mathrm{C}$, whereas air temperatures below $15^{\circ} \mathrm{C}$, a lower threshold of optimum range of temperature for SBR development, were found with the highest frequency during the period following the fifth sowing date.

At Ponta Grossa the air temperature during LWD remained below the optimum range for SBR development most of the time (Figure 2). Throughout the 2014-15 soybean season air temperature ranged from $14.9^{\circ} \mathrm{C}$ to $21.6{ }^{\circ} \mathrm{C}$, whilst throughout the 2015-16 growing season air temperature during LDW stayed between $17.3^{\circ} \mathrm{C}$ and $20.7^{\circ} \mathrm{C}$ (Figure 2). Although air temperatures remained lower than the optimum range, studies have demonstrated that the infectious process may occur under temperatures varying from 15 to $28^{\circ} \mathrm{C}$ (Melching et al., 1989; Del Ponte et al., 2006). 

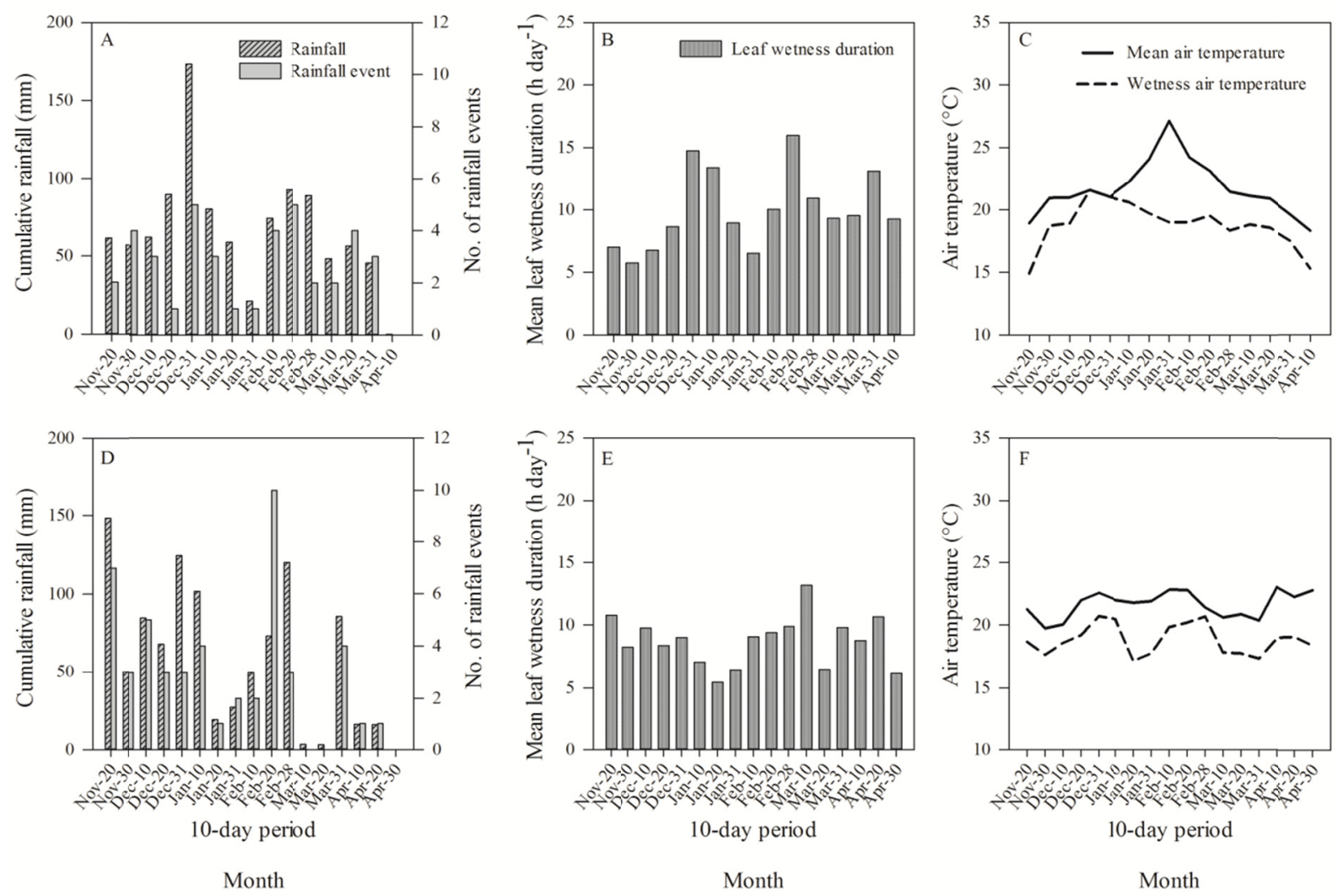

Figure 2. Weather conditions in Ponta Grossa, PR, during 2014-15 (A, B and C) and 2015-16 (D, E and F) soybean crop growing seasons

Although air temperature remained within a favorable range for SBR development in Ponta Grossa, it was noted that lower air temperatures were measured at this location, a fact that might explain low values of final disease severity and AUDPC on some sowing dates (Table 2). Despite air temperature being considered a non-limiting factor for SBR epidemics in Brazil (Del Ponte et al., 2006), the occurrence and establishment of pathogens, e.g., P. pachyrhizi, can be significantly conditioned by the thermal regime (Melching et al., 1989; Cao et al., 2014; Danelli \& Reis, 2016).

In Campo Verde, it is possible to see that air temperatures during LWD were favorable to SBR development at this site (Figure 3), despite the fact that for the majority of the periods in analysis the mean air temperature remained below $25^{\circ} \mathrm{C}$. Throughout the first growing season, air temperatures outside the SBR favorable range were not observed, with the mean air temperature throughout the three crop growing seasons corresponding to $23.2{ }^{\circ} \mathrm{C}$, whilst air temperature during LWD remained at $20.8{ }^{\circ} \mathrm{C}$ (Figure 3). During the second experimental year, air temperature during LWD varied from $21.1^{\circ} \mathrm{C}$ to $23.1^{\circ} \mathrm{C}$. 

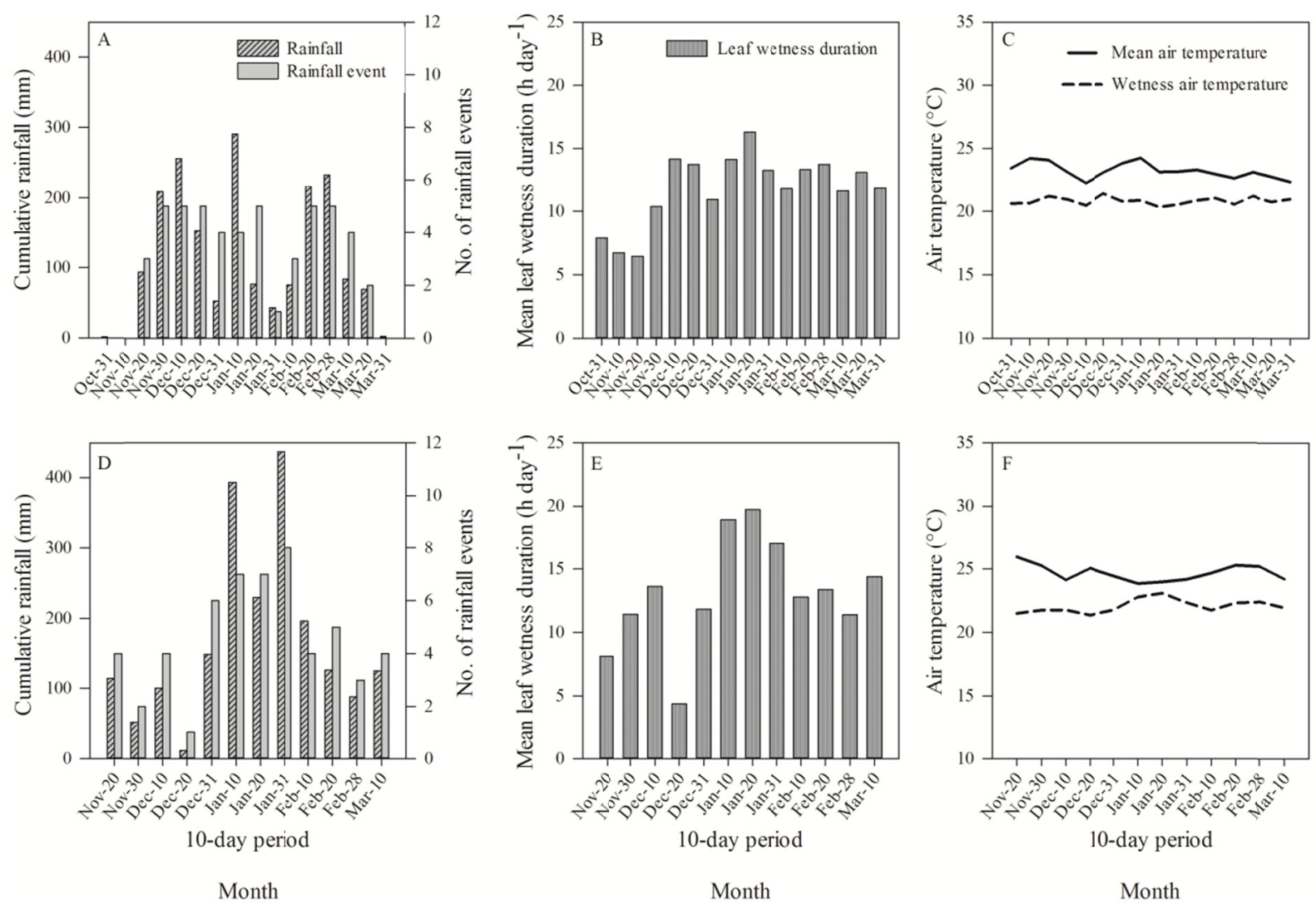

Figure 3. Weather conditions in Campo Verde, MT, during 2014-15 (A, B and C) and 2015-16 (D, E and F) soybean crop growing seasons

Although air temperature was above $25{ }^{\circ} \mathrm{C}$ in some 10-day periods, most of the time this variable remained within the favorable range for SBR occurrence. The favorable environmental condition for SBR occurrence in Campo Verde resulted in high intensity of defoliation, of almost $100 \%$ in most of the assessments (Table 3).

Table 3. Defoliation caused by soybean rust in Campo Verde and Pedra Preta, MT, throughout the 2014-15 and 2015-16 growing seasons and at different sowing dates

\begin{tabular}{|c|c|c|c|c|c|}
\hline \multicolumn{4}{|c|}{ Campo Verde } & \multirow{2}{*}{\multicolumn{2}{|c|}{$\begin{array}{c}\text { Pedra Preta } \\
2015-16\end{array}$}} \\
\hline \multicolumn{2}{|c|}{ 2014-15 } & \multicolumn{2}{|c|}{$2015-16$} & & \\
\hline Sowing date & Defoliation (\%) & Sowing date & Defoliation (\%) & Sowing date & Defoliation (\%) \\
\hline $21 /$ Oct $/ 2014$ & $97.8 \mathrm{~b}$ & $23 / \mathrm{Oct} / 2015$ & $97.8 \mathrm{~b}$ & 06/Nov/2015 & $99.8 \mathrm{a}$ \\
\hline 13/Nov/2014 & $100.0 \mathrm{a}$ & 07/Nov/2015 & $100.0 \mathrm{a}$ & 03/Dec/2015 & $99.5 \mathrm{a}$ \\
\hline 12/Dec/2014 & $100.0 \mathrm{a}$ & 09/Dec/2015 & $100.0 \mathrm{a}$ & - & - \\
\hline $\mathrm{CV}$ & $0.3 \%$ & & $0.3 \%$ & & $0.4 \%$ \\
\hline
\end{tabular}

Note. The defoliation data followed by different letters are statistically different by the Tukey's test $(\alpha=0.05)$.

Throughout most of the 2015-16 growing season, the air temperature at Pedra Preta remained above $25{ }^{\circ} \mathrm{C}$, an upper optimum air temperature threshold for SBR occurrence. However, mean air temperature during the LWD was always lower than $25^{\circ} \mathrm{C}$ and under the presence of a free water film sitting on the plant surface achieved a more favorable range for SBR to occur in the field (Figure 4). According to Del Ponte \& Esker (2008), urediniospore germination and subsequent successful infection are possible under free water conditions on the plant surface. Therefore, considering the presence of such a free water film on the plant surface during the nocturnal period, air mean temperature during LWD was favorable to both infection and establishment of SBR in soybean plants, a fact that promoted high defoliation at the end of the soybean cycle in Pedra Preta (Table 3). 

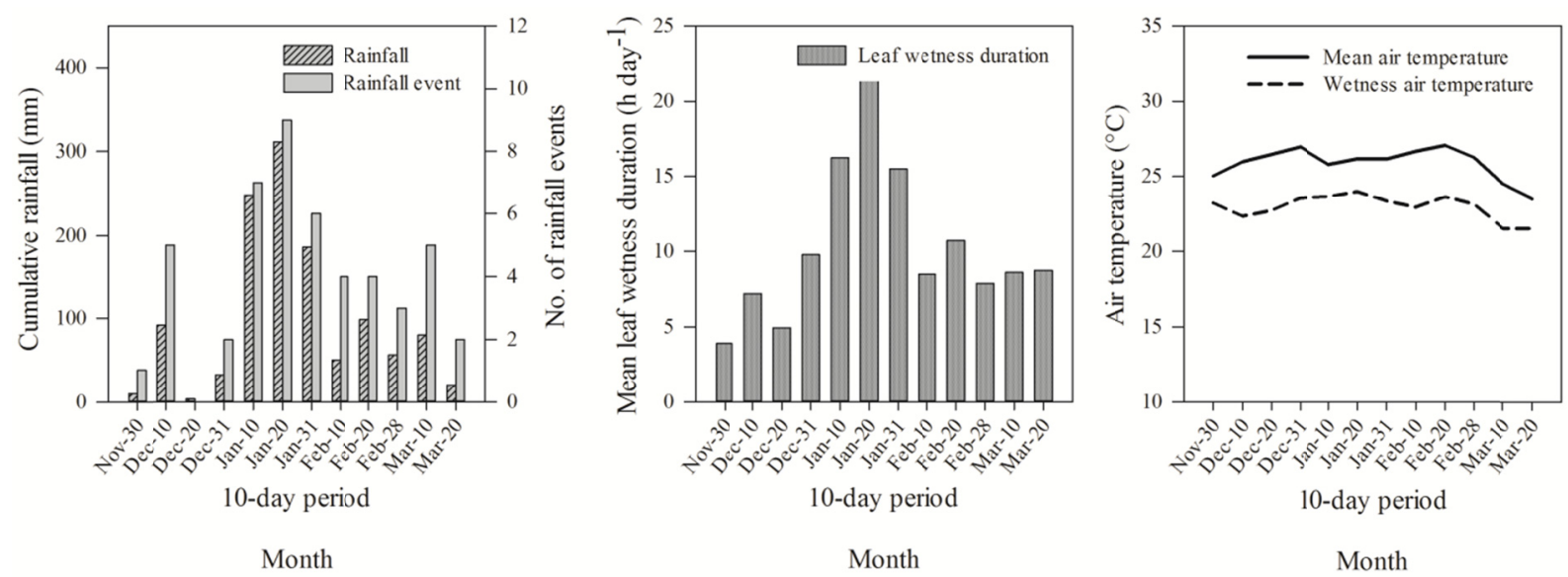

Figure 4. Weather conditions in Pedra Preta, MT, during 2015-16 soybean crop growing season

The influence of night air temperatures on SBR occurrence was demonstrated in Taiwan through the 1980s. Tschanz et al. (1983) determined that SBR epidemics were correlated with the mean night air temperature, evidencing that when the temperature was around $14^{\circ} \mathrm{C}$ no rust lesions occurred at all and that SBR epidemics were retarded. In contrast, whenever a high mean night temperature was recorded $\left(\approx 25^{\circ} \mathrm{C}\right)$, high number of rust lesions were observed in all field trials.

Air humidity is also an important factor in triggering disease occurrence. Water vapor in the environment is directly related to rainfall, irrigation and dew, which can affect LWD and stimulate an initial development of disease, particularly concerning both germination and penetration processes (Del Ponte \& Esker, 2008; Gleason et al., 2008; Rowlandson et al., 2014). According to Melching et al. (1989) the optimum range of LWD to assure SBR infection and spread is between 6 and 12 hours per day. For all stages of the infectious process a LWD ranging from 10 to 22 hours per day is necessary (Del Ponte et al., 2006; Alves et al., 2007).

By analyzing the LWD regime in Piracicaba it was observed that this weather variable remained within an optimum range for SBR occurrence throughout the two soybean growing seasons, except for the fifth sowing date during the 2015-16 season (Figure 1). On the fifth sowing date, a drought occurred in Piracicaba reducing the LWD values by at least three hours per day. Consequently, on average, LWD during the fifth sowing date was $7.0 \mathrm{~h}$ per day as opposed to LWD ranging from 10.1 to $12.1 \mathrm{~h}$ per day on the other sowing dates (Figure 1).

Alves et al. (2007), examining SBR intensity in different soybean cultivars under specific air temperature and LWD regimes, determined a high SBR severity whenever LWD was above a threshold of $12 \mathrm{~h} \mathrm{day}^{-1}$. On the other hand, when LWD was of $6 \mathrm{~h} \mathrm{day}^{-1}$ SBR severity was lower. A similar condition was observed during the last sowing date for the 2015-16 growing season under a mean measured LWD of $7.0 \mathrm{~h} \mathrm{day}^{-1}$. As a consequence of a drop in LWD there were reductions in the SBR final severity (1.9\%) and AUDPC (26.1) (Table 3).

Yorinori et al. (2005) in Brazil and Paraguay also reported the effects of drought on SBR occurrence throughout the 2001-02 soybean season. In this particular case, a lower disease intensity in soybean fields in Paraguay was found compared to disease intensity in Brazil due to drought. In comparison to the lack of an SBR epidemic in Paraguay throughout the same crop growing season in Brazil, significant yield losses as a function of SBR occurrence exceeded $60 \%$, reaching values of $75 \%$ in soybean fields located at the central-east region of Brazil.

For the remaining sowing date in Piracicaba, the favorable conditions for SBR were evidenced and confirmed by the final severity data along with the AUDPC, which presented higher values compared to the drought period. Throughout the 2014-15, final severity remained between 84.3 and $100 \%$ and AUDPC ranged from 837.1 to 2287.5. For the 2015-16 growing season, final severity varied from 65.9 to $100 \%$ and AUDPC ranged from 780.1 to 1969.3 (Table 2).

Increases in final severity and AUDPC as a function of LWD may be realized because high air humidity regimes make the host tissue more susceptible to SBR infection, and as a result disease values can rise (Gabriel et al., 2018). Moreover, for plant diseases caused by a fungus, such as the SBR pathogen, the presence of free water on the plant surface is strongly related to spore formation, longevity, germination, and sporulation (Del Ponte \& Esker, 2008). 
In Ponta Grossa, opposite patterns of LWD comparing the two soybean growing seasons were noticed. Throughout the 2014-15, the LWD remained within a favorable range for SBR occurrence, whilst during 2015-16 for all sowing dates the LWD remained below the lowest optimum threshold for SBR occurrence (Figure 2). Except for the second soybean growing season of 2014-15 in Ponta Grossa, the LWD ranged from 9.8 to $11 \mathrm{~h}$ per day and environmental favorability interfered positively in the values of final severity of the disease, which varied from $66.8 \%$ to $81.0 \%$, whereas AUDPC oscillated between 1073.7 and 1946.8 (Table 2). The opposite outcome was observed on the second sowing date with an SBR final severity equal to $18.6 \%$ along with an AUDPC corresponding to 555.5. Reductions in the disease severity in soybean might be related to depletion of the availability of free water for the pathogen infection process. A significant reduction in LWD was evidenced as soybean plants entered into the reproductive phenological stage, considered the most susceptible phase for disease occurrence (Young et al., 2011; Xavier et al., 2017). During this phenological stage mean LWD decreased from 13.4 to $9.0 \mathrm{~h}$, reaching an average of $6.5 \mathrm{~h}$ during the third 10-day period of January (Figure 2), making the environment less unfavorable to SBR occurrence.

Similar environmental conditions occurred throughout the 2015-16 season in Ponta Grossa. In general, a mean LWD below $9.2 \mathrm{~h}$ per day was observed in this trial (Figure 2). Thus, the lowest values of final severity and AUDPC were obtained on the second, third and fourth sowing dates, and this might be associated with the LWD regime (Table 3). Only on the first sowing date of this crop growing season high values of final severity (73.6\%) and AUDPC (577.2) were observed (Table 2).

Since LWD takes into consideration the presence of free water on the surface of plant tissues under field conditions, changes in LWD might be brought about mainly by the rainfall regime (Sentelhas et al., 2008). Thus, in the current study, it was identified that rainfall frequency and volume were very similar for the periods with low or high LWD in all field trials.

Nevertheless, in the Ponta Grossa 2014-15 soybean growing season regular rainfall regimes were observed during most of a 10-day period, providing in turn a favorable weather condition for SBR occurrence. At this crop growing season the lowest final severity and AUDPC were obtained only on the second sowing date (Table 2). Such a reduction in SBR occurrence might be ascribed to irregular rainfall distribution during the second and third 10-day period in January, totaling 20 days and comprising two rainfall events recorded at Ponta Grossa (Figure 2).

Several studies reported that rainfall itself is considered an epidemic triggering factor for SBR occurrence (Del Ponte et al., 2006; Megeto et al., 2014) since it enhances periods with free water over the plant surfaces. Once rainfall is strongly related to within-canopy spore dispersal, such a variable has a remarkable influence on the performance of fungicide sprays applied for SBR control (Stefanello et al., 2016).

The influence of rainfall on disease scrutinized in the current research might be corroborated by using field data collected from 2015-16 in Ponta Grossa. For this period the highest disease values were recorded throughout the first soybean crop growing season, coinciding with a period of a heavy and regular frequency of rainfall (Figure 2). From the second sowing date lower disease values were observed, with more than a twofold decrease compared to the first sowing date (Table 2). Reductions in disease values may be attributed to dry periods during January, February and March in the Ponta Grossa region (Figure 2).

In Campo Verde regular rainfalls occurred throughout the two soybean growing seasons, making the environment more favorable to SBR occurrence. At this site for both crop growing seasons, high defoliation values were assessed, probably resulting from the influence of a high number of rainfall episodes. Such data shown by season and frequencies over 30 rainfall events per sowing date (Figure 3).

The impact of rainfall on SBR progress was also evaluated in Australia, where Stovold and Smith (1991) verified that severe SBR epidemics happen only in soybean fields under a high rainfall amount. Levy (2005) draws the conclusion that at soybean production areas located in Southern Zimbabwe SBR infection is less severe compared to other agricultural fields in Zimbabwe, due to hot and dry weather in this region.

Effects of uneven rainfall episodes and drought periods can be observed on the fifth sowing date throughout the 2015-16 soybean growing season at Piracicaba. In this particular season, two rainfall events were measured above $1 \mathrm{~mm}$, totaling $8.6 \mathrm{~mm}$ throughout the growing season. The consequence of a dry weather pattern might be built in the disease measured in the field, whose final severity was 1.9\% and AUDPC was 26.1 (Table 2).

Drought periods also had a considerable influence on LWD at Pedra Preta during the first sowing date of the 2015-16 growing season. During this period, it was possible to identify a low LWD corresponding to $3.9 \mathrm{~h}$ per 
day. LWD reached values close to an optimum range for the SBR occurrence only at the end of the fourth 10-day period of the growing season, within which a mean value of $9.8 \mathrm{~h}$ per day was observed.

At Pedra Preta low values of LWD at the beginning of the growing season were not sufficient to affect the SBR in soybean production fields (Table 3). During the period with a low LWD, soybean plants were in the vegetative phase, and at this time soybean plants had a low susceptibility to SBR (Bonde et al., 2013). Thus, throughout the crop growing season in Pedra Preta neither the weather conditions nor the host characteristics favored the SBR occurrence in soybean production fields. However, by the time wet environmental conditions prevailed again and remained in a favorable range for SBR occurrence, soybean plants were at the beginning of flowering stage, coinciding therefore with a period of a high susceptibility to the SBR infection, and as a result disease progress turned out to be favored in the field (Table 3) (Young et al., 2011; Xavier et al., 2017).

Throughout the second soybean growing season at Pedra Preta and for all field trials located in Campo Verde, LWD conditions were favorable for SBR occurrence, especially during the 2015-16 growing season in Campo Verde, within which the mean LWD varied from 13.1 to $15.4 \mathrm{~h}$ per day (Figure 3 ). The favorable environment at these sites resulted in high defoliation levels in the crop, always above $97 \%$.

\subsection{Relationship Between Weather Variables and Soybean Rust Severity}

For Piracicaba, Ponta Grossa, Campo Verde, and Pedra Preta it was possible to observe significant $\mathrm{R}$ values for the correlations with LWD $(\mathrm{R}=0.34)$, Air_LWD $(\mathrm{R}=0.31)$, and $\mathrm{C}$ Rainfall $(\mathrm{R}=0.30)$. When the relationships were performed with final severity, higher $R$ values were obtained for LWD $(R=0.64)$. For the other weather variables, similar patterns in relation to severity at R5.5 were obtained, mainly for Air_T and Rainfall_E (Table 4).

Table 4. Pearson's correlation coefficient for the relationship between weather variables and soybean rust severity assessed at R5.5 phenological stage and at the end of the soybean crop cycle

\begin{tabular}{lllllll}
\hline \multirow{2}{*}{ Severity } & \multirow{2}{*}{$\mathrm{n}$} & \multicolumn{5}{c}{ Pearson correlation values } \\
\cline { 3 - 6 } & & Air_T & Air_LWD & LWD & C_Rainfall & Rainfall_E \\
\hline R5.5 & 96 & $-0.05^{\text {ns }}$ & $0.31^{* *}$ & $0.34^{* *}$ & $0.30^{* *}$ & $0.09^{\text {ns }}$ \\
Final & 60 & $0.26^{*}$ & $0.39^{* *}$ & $0.64^{* *}$ & $0.30^{*}$ & $0.40^{* *}$
\end{tabular}

Note. R5.5 soybean phenological stage, which turns out to be characterized by pods between $75 \%$ and $100 \%$ of grain granulation; $\mathrm{n}=$ number of observations; Air_ $\mathrm{T}=$ mean air temperature $\left({ }^{\circ} \mathrm{C}\right)$; Air_LWD $=$ mean air temperature measured during leaf wetness $\left({ }^{\circ} \mathrm{C}\right) ; \mathrm{LWD}=$ mean leaf wetness duration (hours day ${ }^{-1}$ ); $\mathrm{C}_{-}$Rainfall $=$ cumulative rainfall ( $\mathrm{mm}$ in 30 days); Rainfall_E = rainfall events (days with rain in 30 days). ns represents that Pearson coefficient is not significant; * represents that Pearson coefficient is significant at $\mathrm{P} \leq 0.05$ and $* *$ represents that Pearson coefficient is significant at $\mathrm{P} \leq 0.01$.

The effects of moisture in the soybean canopy on SBR occurrence were also determined by several researchers (Melching et al., 1989; Del Ponte et al., 2006; Megeto et al., 2014; Igarashi et al., 2014; Minchio et al., 2016). Moisture in the environment is mainly affected by rainfall, which also affects air temperature and LWD. All these weather variables affect most fungal diseases, including SBR (Rowlandson et al., 2014).

In this study, assessed SBR severities were more influenced by rainfall and LWD, similar to what was obtained by Del Ponte et al. (2006) when analyzing 34 SBR epidemics all over Brazil. These authors observed that final SBR severity was mainly correlated to total rainfall $(\mathrm{R}=0.95)$ and number of days with $\operatorname{rain}>1 \mathrm{~mm}(\mathrm{R}=0.93)$. On the other hand, air temperature was less correlated to SBR epidemics $(\mathrm{R}=0.47)$. Rainfall increases LWD, which favors infection and sporulation processes (Del Ponte et al., 2006), also promoting production of spores and their survival (Del Ponte \& Esker, 2008).

Using SBR data collected from different Brazilian regions, Megeto et al. (2014) also identified a positive correlation between SBR and variables derived from rainfall. More recently, Minchio et al. (2016) obtained a Pearson coefficient of 0.87 by correlating SBR epidemics in Southern Brazil with accumulated rainfall throughout the soybean cycle. Also, a positive impact of average weekly rainfall on the maximum SBR incidence $(\mathrm{R}=0.39)$ and severity $(\mathrm{R}=0.38)$ was observed by Young et al. (2011) when analyzing SBR epidemics in sentinel plots in Florida, USA.

As mentioned previously, rainfall affects LWD, thus this variable is an important triggering factor for SBR development (Table 4). Melching et al. (1989) initially mentioned the effects of the LWD on SBR, and observed 
that soybean plants when inoculated with P. pachyrhizi urediniospores presented high SBR intensity under $12 \mathrm{~h}$ per day of wetness for three days $\left(\mathrm{R}^{2}=0.97\right)$. Narváez et al. (2010) also observed the influence of the LWD on SBR development in soybean plants, verifying that $18 \mathrm{~h}$ of LWD increased disease severity and the rate of disease spread in the upper canopy.

Therefore, disease factors related to environmental moisture, such as rainfall and LWD, are potential variables to be used as inputs for a disease-warning system to recommend SBR epidemics control in soybean fields in Brazil. Another weather variable that showed positive influence on SBR severity was the air temperature during the leaf wetness duration (Air_LWD), which is also a promising variable to be incorporated into a disease-warning system. Mean air temperature (Air T) showed low correlation with SBR severity, only presenting significant correlation for final severity (Table 4). Similar results were observed by Del Ponte et al. (2006), which, according to these authors are associated with the non-limiting mean temperatures for SBR occurrence during the soybean growing season in the Brazilian producing regions.

\section{Conclusions}

It was possible to conclude that under favorable weather conditions and without any disease control, soybean rust presented a high destructive potential reflected in defoliation and final severity close do $100 \%$. Epidemics of SBR till R5.5 phenological stage were mainly influenced by leaf wetness duration, cumulative rainfall and air temperature during the leaf wetness duration. When SBR severity at the end of the soybean cycle was considered, it was conditioned mainly by leaf wetness duration. Therefore, any disease warning system for SBR should include the variables aforementioned, together or individually, as inputs.

\section{Acknowledgements}

The first author thanks the São Paulo State Research Foundation (FAPESP) along with the Coordination for the Improvement of Higher Education Personnel (CAPES) funding agencies for the financial support provided to the current study (grant process number 2014/05677-1 and 2016/06764-0). The authors are also very grateful to João V. de Mattos, Jessica J. Jaguela and Bruno Marcantes for their remarkable assistance in field trials carried out at Ponta Grossa, PR, Brazil plus Mato Grosso Foundation for the infrastructure and staff committed to conduction of field trials set up in the State of Mato Grosso. Special thanks are devoted to Dr. Janice E. Pittis for the impeccable proofreading and remarks regarding the English of our contribution.

\section{References}

Alvares, C. A., Stape, J. L., Sentelhas, P. C., Gonçalves, J. L., \& Sparovek, G. (2013). Köppen's climate classification map for Brazil. Meteorologische Zeitschrift, 22(6), 711-728. https://doi.org/10.1127/ 0941-2948/2013/0507

Alves, M. C., Pozza, E. A., Ferreira, J. B., Araújo, D. V., Costa, J. C. B., Deuner, C. C., ... Machado, J. C. (2007). The effects of temperature and leaf wetness periods on the development of soybean rust in the cultivars Conquista, Savana and Suprema. Summa Phytopathologica, 33(3), 239-244. https://doi.org/10.1590/ S0100-54052007000300005

Bonde, M. R., Nester, S. E., \& Berner, D. K. (2012). Effects of daily temperature highs on development of Phakopsora pachyrhizi on soybean. Phytopathology, 102(8), 761-768. https://doi.org/10.1094/PHYTO-0112-0011-R

Bonde, M. R., Nester, S. E., \& Berner, D. K. (2013). Effects of frequency of "extreme" temperature highs on development of soybean rust. Phytopathology, 103(7), 708-716. https://doi.org/10.1094/PHYTO-09-120250-R

Cao, X., Yao, D., Xu, X., Zhou, Y., Ding, K., Duan, X., ... Luo, Y. (2015). Development of weather and airborne inoculum-based models to describe disease severity of wheat powdery mildew. Plant Disease, 99(3), 395-400. https://doi.org/10.1094/ PDIS-02-14-0201-RE

Danelli, A. L. D., \& Reis, E. M. (2016). Quantification of incubation, latent and infection periods of Phakopsora pachyrhizi in soybean, according to chronological time and degree-days. Summa Phytopathologica, 42(1), 11-17. https://doi.org/10.1590/0100-5405/1920

Del Ponte, E. M., \& Esker, P. D. (2008). Meteorological factors and Asian soybean rust epidemics: A systems approach and implications for risk assessment. Scientia Agricola, 65(SP), 88-97. https://doi.org/10.1590/ S0103-90162008000700014 
Del Ponte, E. M., Godoy, C. V., Li, X., \& Yang, X. B. (2006). Predicting severity of Asian soybean rust epidemics with empirical rainfall models. Phytopathology, 96(7), 797-803. https://doi.org/10.1094/ PHYTO-96-0797

Gabriel, M., Muraro, D. S., Rosa, G. M., Wastowski, A. D., Kulczynski, S. M., Silva, J. C., ... Stumm, J. O. (2018). Chemical control of Asian soybean rust and its effect in the yield and quality of soybean seeds. Journal of Agriculture Science, 10(10), 518-526. https://doi.org/10.5539/jas.v10n10p518

Gillespie, T. J., \& Sentelhas, P. C. (2008). Agrometeorology and plant disease management: A happy marriage. Scientia Agricola, 65(SP), 71-75. https://doi.org/10.1590/S0103-90162008000700012

Gleason, M. L. Duttweiler, K. B., Batzer, J. C., Taylor, S. E., Sentelhas, P. C., Monteiro, J. E. B. A., \& Gillespie, T. J. (2008). Obtaining weather data for input to crop disease-warning systems: Leaf wetness duration as a case study. Scientia Agricola, 65(SP), 76-87. https://doi.org/10.1590/S0103-90162008000700013

Godoy, C. V., Koga, L. J., \& Canteri, M. G. (2006). Diagrammatic scale for assessment of soybean rust severity. Fitopatologia Brasileira, 31(1), 63-68. https://doi.org/10.1590/S0100-41582006000100011

Hartman, G. L., Rupe, J. C., Sikora, E. J., Domier, L. L., Davis, J. A., \& Steffey, K. L. (2016). Compendium of Soybean Diseases and Pests (5th ed.). The American Phytopathological Society. https://doi.org/10.1094/ 9780890544754.005

Hirano, M., Hikishima, M., Silva, A. J., Xavier, S. A., \& Canteri, M. G. (2010). Validation of diagrammatic scale for estimating defoliation caused by the Asian rust in soybeans. Summa Phytopathologica, 36(3), 248-250. https://doi.org/10.1590/S0100-54052010000300012

Igarashi, W. T., Silva, M. A. A., Igarashi, S., Abi Saab, O. J. G., \& França, J. A. (2014). Leaf wetness duration and percentage based on inter-row spacing, and influence on Asian soybean rust. Summa Phytopathologica, 40(2), 123-127. https://doi.org/10.1590/0100-5405/1969

Kranz, J., \& Rotem, J. (2012). Experimental techniques in plant disease epidemiology. Springer Science \& Business Media.

Levy, C. (2005). Epidemiology and chemical control of soybean rust in southern Africa. Plant Disease, 89(6), 669-674. https://doi.org/10.1094/PD-89-0669

Megeto, G. A. S., Oliveira, S. R. M., Del Ponte, E. M., \& Meira, C. A. A. (2014). Decision tree for classification of soybean rust occurence in commercial crops based on weather variables. Engenharia Agrícola, 34(3), 590-599. https://doi.org/10.1590/S0100-69162014000300021

Melching, J. S., Dowler, W. M., Koogle, D. L., \& Royer, M. H. (1989). Effects of duration, frequency, and temperature of leaf wetness periods on soybean rust. Plant Disease, 73(2), 117-122. https://doi.org/10.1094/ PD-73-0117

Minchio, C. A., Canteri, M. G., Fantin, L. H., \& Silva, M. A. A. (2016). Soybean rust epidemics in Rio Grande do Sul explained by ENSO phenomenon and off-season disease incidence. Summa Phytopathologica, 42(4), 321-326. https://doi.org/10.1590/0100-5405/2219

Narváez, D. F., Jurick, W. M., Marois, J. J., \& Wright, D. L. (2010). Effects of surface wetness periods on development of soybean rust under field conditions. Plant Disease, 94(2), 258-264. https://doi.org/10.1094/ PDIS-94-2-0258

Rowlandson, T., Gleason, M., Sentelhas, P., Gillespie, T., Thomas, C., \& Hornbuckle, B. (2014). Reconsidering leaf wetness duration determination for plant disease management. Plant Disease, 99(3), 310-319. https://doi.org/10.1094/PDIS-05-14-0529-FE

Sentelhas, P. C., Dalla Marta, A., Orlandini, S., Santos, E. A., Gillespie, T. J., \& Gleason, M. L. (2008). Suitability of relative humidity as an estimator of leaf wetness duration. Agricultural and Forest Meteorology, 148(3), 392-400. https://doi.org/10.1016/j.agrformet.2007.09.011

Stefanello, M. T., Balardin, R. S., Minuzzi, S. G., Favera, D. D., Marques, L. N., Pezzini, D. T., \& Ebone, A. (2016). Effect of the interaction between fungicide application time and rainfall simulation interval on Asian soybean rust control effectiveness. Semina: Ciências Agrárias, 37(6), 3881-3892. https://doi.org/ $10.5433 / 1679-0359.2016 \mathrm{v} 37 \mathrm{n} 6 \mathrm{p} 3881$

Stovold, G. E., \& Smith, H. J. P. (1991). The prevalence and severity of diseases in the coastal soybean crop of New South Wales. Australian Journal of Experimental Agriculture, 31(4), 545-550. https://doi.org/10.1071/ EA9910545 
Strange, R. N., \& Scott, P. R. (2005). Plant disease: A threat to global food security. Annual Review of Phytopathology, 43(1), 83-116. https://doi.org/10.1146/annurev.phyto.43.113004.133839

Tschanz, A. T., Wang, T. C., \& Tsai, B. Y. (1983). Recent advances in soybean rust research. International Symposium on Soybean in Tropical and Sub-tropical Cropping Systems (pp. 237-245). Tsukuba, Japan.

Xavier, S. A., Martins, D. C., Fantin, L. H., \& Canteri, M. G. (2017). Older leaf tissues in younger plants are more susceptible to soybean rust. Acta Scientiarum. Agronomy, 39(1), 17-24. https://doi.org/10.4025/ actasciagron.v39i1.30638

Yorinori, J. T., Paiva, W. M., Frederick, R. D., Costamilan, L. M., Bertagnolli, P. F., Hartman, G. E., ... Nunes, J. (2005) Epidemics of soybean rust (Phakopsora pachyrhizi) in Brazil and Paraguay from 2001 to 2003. Plant Disease, 89(6), 675-677. https://doi.org/10.1094/PD-89-0675

Young, H. M., Marois, J. J., Wright, D. L., Narváez, D. F., \& O’Brien, G. K. (2011). Epidemiology of soybean rust in soybean sentinel plots in Florida. Plant Disease, 95(6), 744-750. https://doi.org/10.1094/ PDIS-07-10-0552

\section{Copyrights}

Copyright for this article is retained by the author(s), with first publication rights granted to the journal.

This is an open-access article distributed under the terms and conditions of the Creative Commons Attribution license (http://creativecommons.org/licenses/by/4.0/). 